\title{
Motivasi Orang Tua Memilih Sekolah Berbasis Islam
}

\author{
Rasi Muliya1, Ahmad Rivauzi ${ }^{2}$ \\ rasi.muliya98@gmail.com¹, ahmadrivauzi@fis.unp.ac.id ${ }^{2}$ \\ Universitas Negeri Padang ${ }^{1,2}$
}

\begin{tabular}{l}
\hline ARTICLE INFO \\
\hline Article history: \\
Received, 5 August 2021 \\
Revised, 24 August 2021 \\
Accepted, 30 November \\
2021 \\
\hline
\end{tabular}

\section{Keywords:}

Peranan, Orang tua,

Pembinaan Akhlak, Remaja

\section{Clonflict of Interest:}

None

\section{Funding:}

None

\begin{abstract}
Penelitian ini bertujuan untuk mendeskripsikan motivasi intrinsic, mendeskripsikan motivasi ekstrinsik, dan mendeskripsikan harapan orang tua setelah menyekolahkan anaknya di Sekolah Dasar Islam Terpadu Albina Kecamatan Koto Baru Kabupaten Dharmasraya. Metode yang digunakan adalah penelitian kualitatif. Sedangkan teknik yang digunakan yaitu wawancara, observasi, dan dokumentasi. Teknik analisis data, ada tiga tahapan yaitu reduksi data, penyajian data, dan penarikan kesimpulan menggunakan teori motivasi dari Abraham Maslow (Teori Kebutuhan), teori motivasi VROOM (Teori Harapan), teori motivasi Achievement Mc Clelland (Teori Kebutuhan Berprestasi), dan teori motivasi Herzberg (Teori Dua Faktor), motivasi dari orang tua yang menyekolahkan anaknya di SDIT Albina Kecamatan Koto Baru Kabupaten Dharmasraya. Hasil penelitian ini menunjukkan bahwa motivasi intrinsik yaitu pemenuhan rasa aman orang tua, rasa cinta dan kasih sayang, dan harapan agar anak mempunyai keterampilan dan pengetahuan keagamaan (berprestasi), serta harapan terwujudnya anak Saleh dan solehah serta berakhlak mulia. Motivasi ekstrinsik, yaitu visi, misi, dan tujuan sekolah, kurikulum sekolah, sistem pelayanan, dan sarana dan prasarana.
\end{abstract}

Corresponding Author: Rasi Muliya, Department Islamic Education, Faculty of Social Science, Universitas Negeri Padang, Indonesia, Email: miahastarina0210@gmail.com Phone: +6282383912828

\section{Pendahuluan}

Kenakalan remaja menjadi salah satu peristiwa yang semakin sering ditemukan sehingga menimbulkan kekhawatiran tersendiri bagi orang tua. Terdapat beberapa bentuk kenakalan remaja yang umumnya sering dilakukan seperti melakukan tawuran, baik tawuran sesama remaja atau pelajar bahkan melawan aparat keamanan sebagai salah satu bentuk protes dan perlawanan terhadap otoritas yang ada, pelanggaran lalu lintas, perampokan dan pencurian, penyalahgunaan obat-obatan terlarang hingga perilaku seks bebas. Badan Kependudukan dan Keluarga Berencana Nasional (BKKBN) bahwa pelaku kenakalan remaja umumnya dilakukan oleh anak usia remaja yaitu usia 10 hingga 24 tahun dan berstatus belum menikah sehingga dapat diartikan pelajar yang berusia dibawah 24 tahun dan belum menikah masih tergolong sebagai usia remaja, tidak terkecuali mahasiswa dengan usia 24 tahun ke bawah. (Brief Notes Lembaga Demografi, 2017). 
Rasi Muliya dan Ahmad Rivauzi: Motivasi Orang Tua Memilih Sekolah Berbasis...

Terdapat laporan mengenai peningkatan angka kasus kenakalan remaja yang diterima oleh Komisi Perlindungan Anak Indonesia.Sejak tahun 2015 kasus kenakalan remaja terus meningkat hingga tahun 2018 dengan angka sebanyak 4.885 kasus. Beberapa di antaranya yaitu kasus pencurian dan perampokan, kasus tawuran, kasus penyalahgunaan obat-obat terlarang, kasus kejahatan siber, dan kasus kekerasan seksual (Republika.co.id, 8 Januari 2018). Salah satu contoh perilaku kenakalan remaja yang dilakukan oleh mahasiswa adalah pelanggaran lalu lintas di Surabaya yang tercatat dengan total pelanggaran sebanyak 1.578 pelanggarlalu lintas dalam kurun waktu 3 minggu (21 hari). Hal tersebut menyebabkan mahasiswa menempati posisi kedua tertinggi pada tahun 2018 sebagai pelanggar lalu lintas dengan posisi pertama yaitu karyawan atau pekerja sebagai pelanggar lalu lintas (Surya, 2018) (dalam Nafisa). Hal ini menjadikan banyak orang tua semakin berusaha memilih sekolah yang baik untuk anak mereka.

Tujuan penelitian ini adalah untuk mendeskripsikan motivasi instrinsik, motivasi ekstrinsik dan harapan orang tua dalam menyekolahkan anaknya di SD Islam Terpadu Albina Kecamatana Koto Baru Kabupaten Dharmasraya.

\section{Tinjauan Pustaka}

Motivasi instrinsik dan ekstrinsik diambil dari konsep motivasi menurut Abraham Maslow. Motivasi berasal dari bahasa Inggris Motive yang berarti mendorong atau menggerakkan. Motivasi diartikan sebagai daya penggerak yang terdapat dalam tubuh yang menggerakkan tindakannya. Motivasi tidak berdiri sendiri, tetapi saling terkait dengan faktor lain, termasuk faktor eksternal dan internal. Apa yang mempengaruhi motivasi disebut motivasi. Motivasi adalah gejala psikologis, yang diwujudkan sebagai dorongan seseorang untuk bertindak secara sadar untuk tujuan tertentu.Motivasi juga dapat berupa kerja keras yang dapat membuat seseorang atau sekelompok orang melakukan tindakan untuk melakukan sesuatu karena ingin mencapai suatu tujuan yang diinginkan atau merasa puas dengan perilakunya.Motivasi memegang peranan yang strategis dalam kegiatan belajar, tanpa motivasi tidak ada pembelajaran, dan tanpa motivasi tidak ada kegiatan belajar.Untuk mengoptimalkan peran motivasi, prinsip motivasi belajar tidak hanya harus diketahui, tetapi juga dijelaskan dalam kegiatan sehari-hari (Prihatanta, 2015).

Menurut Sudarwan (2002:2) (dalam Suprihatin, 2015) Motivasi didefinisikan sebagai suatu kekuatan, dorongan, kebutuhan, semangat, tekanan atau mekanisme psikologis, yang mendorong seseorang atau sekelompok orang untuk mencapai prestasi tertentu berdasarkan apa yang diinginkannya. Hakim (2007:26) (dalam Suprihatin, 2015) berpendapat bahwa konsep motivasi adalah suatu dorongan kehendak, yang menyebabkan seseorang melakukan tindakan untuk mencapai tujuan tertentu.

Jenis-jenis motivasi menurut Wina Sanjaya (2010: 256) (dalam Emda, 2018) dilihat dari sifatnya motivasi dapat dibedakan antara motivasi instrinsik dan motivasi ekstrinsik. Motivasi instrinsik adalah motivasi yang muncul dari dalam diri individu misalkan, siswa belajar karena didorong oleh keinginannya sendiri menambah pengetahuan, atau seseorang berolahraga tenis karena memang ia mencintai olahraga tersebut. Jadi dengan demikian, dalam motivasi instrinsik tujuan yang ingin dicapai ada dalam kegiatan itu sendiri.

Sedangkan motivasi ekstrinsik adalah motivasi yang datang dari luar diri. Misalkan siswa belajar dengan penuh semangat karena ingin mendapatkan nilai yang bagus, seseorang berolahraga karena ingin menjadi juara dalam suatu turnamen. Dengan demikian dalam motivasi ekstrinsik tujuan yang ingin dicapai berada diluar kegiatan itu. Dalam proses pembelajaran, motivasi instrinsik sulit untuk diciptakan karena motivasi ini datangnya dari dalam diri siswa. Kita tidak akan tahu seberapa besar motivasi instrinsik yang menyertai perbuatan siswa. Hal yang mungkin dapat dilakukan adalah dengan mengembangkan motivasi ekstrinsik untuk menambah dorongan kepada siswa agar lebih giat belajar.

Adapun fungsi motivasi berdasarkan Hamalik (2011: 108) (dalam Kompri, 2015: 5) meliputi sebagai berikut:1. Mendorong insan buat berbuat atau bertindak. Berfungsi menjadi 
penggerak buat melakukan sesuatu. Segala kegiatan yang dilaksanakan terdorong oleh motivasi dan keinginan yang terdapat pada diri insan.2.Menentukan arah yang hendak dicapai, artinya mengarahkan perbuatan pencapaian tujuan yang diinginkan.3. Menyeleksi perbuatan. Maksudnya seberapa besar atau kecilnya motivasi yang dilakukan menentukan cepat atau lambatnya suatu pekerjaan.

Teori-teori Motivasi (dalam Prihartanta, 2015) sebagai berikut:

a. Abraham Maslow

Mengemukakan (1943: 1970) bahwa pada dasarnya manusia memiliki kebutuhan pokok, ditunjukkan dalam 5 tingkatan yang dikenal dengan sebutan Hinarki Kebutuhan Maslo, yaitu sebagai berikut: 1). Kebutuhan fisiologis: rasa lapar, haus dan lain-lain, 2) Kebutuhan rasa aman: merasa aman dan terlindung, jauh dari bahaya, 3). Kebutuhan akan rasa cinta dan rasa memiliki: berafiliasi dengan orang lain, diterima, memiliki, 4). Kebutuhan akan penghargaan: berprestasi, berkompetensi dan mendapatkan dukungan serta pengakuan, 5). Kebutuhan aktualisasi diri: kebutuhan kognitif (mengetahui, memahami, menjelajahi), kebutuhan estetik (keserasian, keteraturan dan keindahan), kebutuhan aktualiasasi diri (mendapatkan kepuasan diri dan menyadari potensinya).

b. Teori Motivasi VROOM (Teori Harapan) (1964)

Tentang cognitive theory of motivation menjelaskan mengapa seseorang tidak akan melakukan sesuatu yang ia yakini tidak dapat melakukannya, sekalipun hasil dari pekerjaan itu sangat diinginkan. Menurut Vroom, tinggi rendahnya motivasi seseorang ditentukan oleh tiga komponen yaitu: 1). Ekspektasi (harapan riil): keberhasilan pada suatu tugas, 2). Instrumentalis (harapan ganjaran) yaitu penilaian tentang yang akan terjadi, jika berhasil dalam melakukan suatu tugas (keberhasilan tugas untuk mendapatkan outcome tertentu) 3). Valensi (harapan penerimaan) yaitu respon terhadap outcome seperti perasaan positif, netral atau negatif. Motivasi tinggi jika usaha menghasilkan sesuatu yang melebihi harapan. Motivasi rendah jika usahanya menghasilkan kurang dari yang diharapkan.

c. Teori Motivasi ACHIEVEMENT Mc CLELLAND (Teori Kebutuhan Berprestasi) (1961)

Menyatakan bahwa ada tiga hal penting yang menjadi kebutuhan manusia, yaitu: 1). Need for achievement (kebutuhan akan prestasi), 2). Need for affiliation (kebutuhan akan hubungan sosial/hampir sama dengan soscialneed-nya Maslow), 3). Need for Power (dorongan untuk mengatur).

d. Teori Motivasi HERZBERG (Teori dua faktor)

Menurut Herzberg (1966), ada dua jenis faktor yang mendorong seseorang untuk berusaha, yaitu: mencapai kepuasan dan menjauhkan diri dari ketidakpuasan. Dua faktor itu disebutkan faktor hygiene (faktor ekstrinsik) dan faktor motivator (faktor instrinsik). Faktor hygiene (faktor ekstrinsik) memotivasi seseorang untuk keluar dari ketidakpuasan, termasuk didalamnya adalah hubungan antar manusia, imbalan, kondisi lingkungan, dan sebagainya. Sedangkan faktor motivator (faktor instrinsik) memotivasi seseorang untuk berusaha mencapai kepuasan, yang termasuk didalamnya adalah achievement, pengakuan, kemajuan tingkat kehidupan, dan sebagainya.

\section{Metode}

Jenis penelitian ini adalah jenis penelitian kualitatif yaitu: prosedur penelitiannya berupa kata-kata tertulis dan lisan dari informan yang dapat diamati. (Lexy J. Moleong, 2017:26). Peneliti menggunakan jenis pendekatan yang temuan-temuannya tidak diperoleh melalui prosedur statistik atau bentuk cara-cara hitungan lainnya yang menggunakan angka. Jenis penelitian ini adalah penelitian studi kasus. Studi kasus yaitu penelitian yang berusaha untuk memperoleh gambaran secara lengkap dan detail tentang kejadian dan fenomena tertentu pada suatu subjek dan objek yang memiliki kekhasan. Dengan demikian, pelaksanaan penelitian dengan menggunakan metode studi kasus adalah menggali informasi sebanyakbanyaknya dan sedalam-dalamnya kemudian mendiskripsikannya dalam bentuk naratif sehingga memberikan gambaran secara utuh tentang fenomena yang terjadi. (Sanjaya, 2013: 
Rasi Muliya dan Ahmad Rivauzi: Motivasi Orang Tua Memilih Sekolah Berbasis...

47). Kasus dalam penelitian ini adalah Motivasi Orang Tua Dalam Sekolah Berbasis Islam Di Islam Terpadu Albina Kecamatan Koto Baru Kabupaten Dharmasraya.

Adapun subyek penelitian ini adalah pihak-pihak yang diteliti oleh peneliti, yang menjadi subyek penelitian ini adalah orang tua yang menyekolahkan anaknya di SDIT Albina Kecamatan Koto Baru Kabupaten Dharmasraya.Dalam penelitian kualitatif, instrument primer pengumpulan data adalah manusia atau peneliti itu sendiri dengan cara mengamati, bertanya, mendengar, meminta data penelitian. Peneliti harus menerima data yang valid, sehingga tidak asal narasumber yang diwawancarai.Oleh karena itu, kondisi informan pun harus jelas sinkron dengan kebutuhan dan supaya bisa diakui kebenaran datanya.Teknik pengumpulan data merupakan langkah yang paling strategis dalam penelitian, karena tujuan utamanya adalah mengumpulkan data.Untuk memperoleh data yang alami dan objektif di lokasi penelitian, penulis menggunakan teknik pengumpulan data dengan melakukan langkah-langkah yaitu: metode wawancara, observasi dan dokumentasi.

Setelah data diperoleh, maka selanjutnya dilakukan penganalisisan data. Menurut Neong Muhadjir (1998: 104) (dalam Rijali, 2019) mengemukakan pengertian analisis data sebagai "upaya mencari dan menata secara sistematis catatan hasil observasi, wawancara, dan lainnya untuk meningkatkan pemahaman peneliti tentang kasus yang diteliti dan menyajikannya sebagai temuan bagi orang lain. Sedangkan untuk meningkatkan pemahaman tersebut analisis perlu dianjurkan dengan berupaya mencari makna." Teknik penganalisisan data yang digunakan adalah: reduksi data, penyajian data, dan penarikan kesimpulan. Dalam penelitian kualitatif, untuk menetapkan keabsahan data diperlukan teknik pemeriksaan. Pelaksanaan pemeriksaan didasarkan atas sejumlah kriteria tertentu, untuk mengatasi keabsahan tersebut, dalam penelitian ini dengan menggunakan teknik yang antara lain:1) triangulasi: triangulasi sumber, triangulasi teknik, dan triangulasi waktu. 2) menggunakan bahan referensi.

\section{Hasil dan Pembahasan}

Berdasarkan hasil wawancara dan observasi dengan informan, hasil analisis secara nyata mendapati bahwa motivasi instrinsik orang tua dalam menyekolahkan anaknya di SD Islam Terpadu Albina sebagai berikut:

a. Motivasi instrinsik orang tua meyekolahkan anaknya di SD Islam Terpadu Albina Kecamatan Koto Baru Kabupaten Dharmasraya

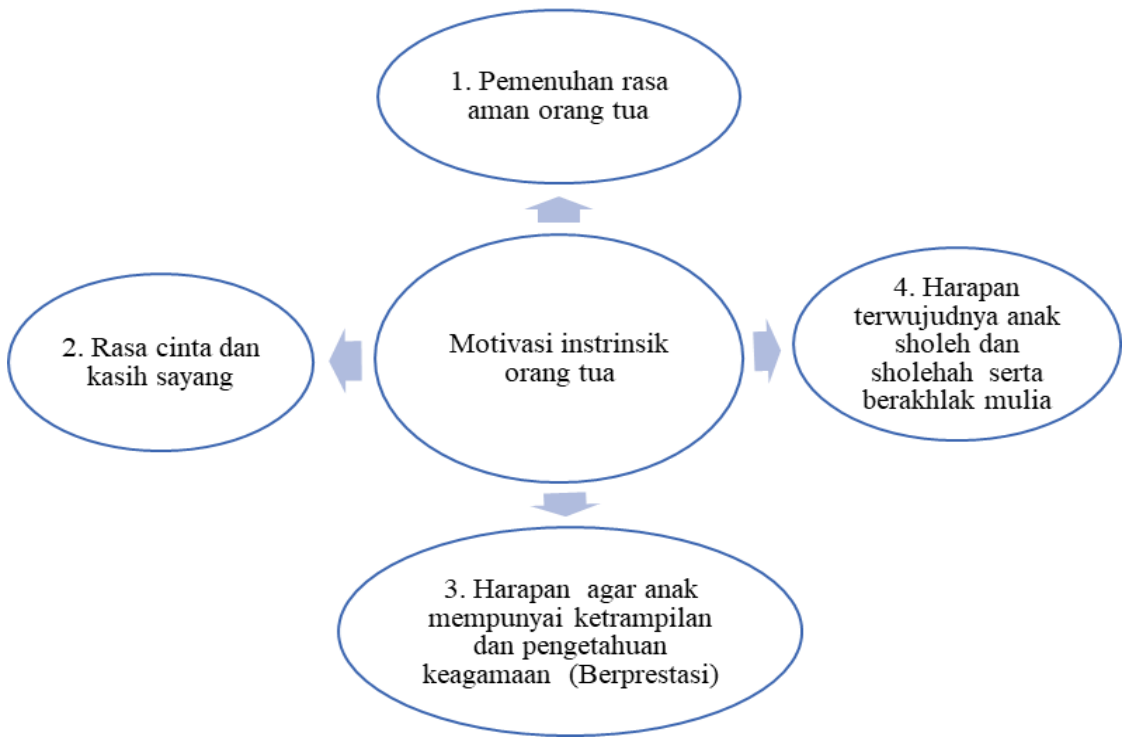

Gambar 1. Deskripsi Motivasi Instrinsik Orang Tua Meyekolahkan Anaknya di SD Islam Terpadu Albina Kecamatan Koto Baru Kabupaten Dharmasraya 
Tema 1: Pemenuhan Rasa Aman Orang Tua. Orang tua berharap akan adanya kebutuhan rasa aman, yaitu orang tua merasa anak-anaknya aman dan terlindungi serta jauh dari bahaya. Ketika anak berangkat sekolah dan sesampainya di sekolah anak selalu di pantau serta di awasi oleh guru-gurunya. Dapat dilihat dari hasil wawancara dengan informan pada table 1.1 sebagai berikut:

\begin{tabular}{|c|c|c|}
\hline Tema & Informan & Petikan Wawancara \\
\hline \multirow[t]{2}{*}{$\begin{array}{l}\text { Pemenuhan } \\
\text { rasa aman } \\
\text { orang tua }\end{array}$} & 6 & $\begin{array}{l}\text { Dari anak saya berpamitan berangkat ke sekolah dengan bus } \\
\text { angkutan sekolahnya dan sesampai di sekolah pun anak } \\
\text { langsung masuk ke kelas tanpa harus keluyuran, karna ada } \\
\text { guru yang memantau setiap kegiatannya. Hal itu membuat } \\
\text { saya merasa aman terhadap kegiatan anak saya. }\end{array}$ \\
\hline & 4 & $\begin{array}{l}\text { Dengan adanya mobil antar jemput sekolah, mengurangi } \\
\text { kekhawatiran saya terhadap anak, saya merasa aman bahwa } \\
\text { anak sesampainya di sekolah bisa langsung masuk kelas siap } \\
\text { untuk belajar. }\end{array}$ \\
\hline
\end{tabular}

Tema 2: Rasa cinta dan kasih sayang. Orang tua berharap bahwa sekolah bisa memenuhi rasa cinta dan kasih sayangnya terhadap anak di sekolah, menganggap anak seperti anaknya sendiri, di ayomi, di didik, serta berlaku adil tanpa adanya pilih kasih terhadap anak.

Tabel 1.2. Petikan Wawancara Tentang Motivasi Rasa Cinta dan Kasih Sayang

\begin{tabular}{|l|l|l|}
\hline Tema & Informan & Petikan Wawancara \\
\hline $\begin{array}{l}\text { Rasa cinta } \\
\text { dan kasih } \\
\text { sayang }\end{array}$ & 1 & $\begin{array}{l}\text { Saya sangat berharap pihak sekolah memberikan yang terbaik } \\
\text { terhadap anak saya, mendidik serta mengayomi anak saya } \\
\text { kepada hal-hal yang positif agar tercapainya pendidikan yang } \\
\text { diinginkan }\end{array}$ \\
& $\begin{array}{l}\text { Harapan saya terhadap sekolah bisa mendidik anak saya ke } \\
\text { arah yang lebih baik, serta memberikan rasa cinta dan kasih } \\
\text { sayang yang kami berikan di rumah juga sama hal nya yang di } \\
\text { dapatkan di sekolah }\end{array}$ \\
\end{tabular}

Tema 3: Harapan agar anak mempunyai ketrampilan dan pengetahuan keagamaan (Berprestasi). Harapan selanjutnya yaitu agar anak-anak mereka menjadi anak yang berprestasi tidak hanya dalam ilmu pengetahuan umum saja tetapi juga dalam hal agama.

Tabel 1.3. Petikan Wawancara Tentang Motivasi Harapan Agar Anak Mempunyai Ketrampilan dan Pengetahuan Keagamaan (Berprestasi).

\begin{tabular}{|c|c|c|}
\hline Tema & Informan & Petikan Wawancara \\
\hline $\begin{array}{l}\text { Harapan } \\
\text { agar anak } \\
\text { mempunyai } \\
\text { ketrampilan } \\
\text { dan } \\
\text { pengetahuan } \\
\text { keagamaan }\end{array}$ & 9 & $\begin{array}{l}\text { Saya sangat berharap sekali semoga dengan } \\
\text { menyekolahkan anak saya ke SDIT Albina, anak saya } \\
\text { menjadi anak yang berprestasi, anak saya tidak hanya } \\
\text { pintar dalam ilmu pengetahuan saja tetapi yang paling } \\
\text { utama sekali pintar dalam ilmu agama serta mempunyai } \\
\text { ketrampilan agar menjadi anak yang bisa membanggakan } \\
\text { orang tua, dirinya sendiri dan bahkan orang lain. }\end{array}$ \\
\hline
\end{tabular}


Rasi Muliya dan Ahmad Rivauzi: Motivasi Orang Tua Memilih Sekolah Berbasis...

$\begin{array}{cll}\text { (Berprestasi) } & 1 & \text { Saya berharap anak saya menjadi anak yang berprestasi } \\ & \text { baik itu dalam bidang umum maupun dalam bidang } \\ & \text { keagamaan yang terpenting, serta tidak kalah dengan } \\ \text { sekolah-sekolah lain yang mempunyai ketrampilan yang } \\ \text { bagus sehingga meraih berbagai prestasi. }\end{array}$

Tema 4: Harapanterwujudnya anak yang Saleh dan Salehah serta berakhlak mulia. Orang tua berharap agar anaknya menjadi anak yang Saleh dan Salehah dan memiliki akhlak yang baik karena di lihat pada zaman sekarang ini dihadapkan pada masalah moral dan akhlak yang cukup serius, yang kalau dibiarkan akan merusak harapan bangsa.

Tabel 1.4. Petikan Wawancara Tentang Motivasi Harapan Terwujudnya Anak yang Saleh dan Salehah serta Berakhlak Mulia

\begin{tabular}{|c|c|c|}
\hline Tema & Informan & Petikan Wawancara \\
\hline \multirow[t]{2}{*}{$\begin{array}{l}\text { Harapan } \\
\text { terwujudnya } \\
\text { anak yang } \\
\text { Saleh dan } \\
\text { Salehah } \\
\text { serta } \\
\text { berakhlak } \\
\text { mulia } \\
\end{array}$} & 9 & $\begin{array}{l}\text { Akhlak menjadi alasan utama saya dalam menyekolahkan } \\
\text { anak saya di SDIT Albina supaya anak saya bisa menjadi } \\
\text { anak yang berakhlak mulia serta menjadi anak yang Saleh } \\
\text { dan Salehah tentunya. Dan didukung dengan guru yang } \\
\text { mencontohkan anak untuk berbuat baik, karena guru } \\
\text { sangat berperan dalam pembentukan pribadi anak selama } \\
\text { di sekolah }\end{array}$ \\
\hline & 10 & $\begin{array}{l}\text { Ante berharap agar anak ante menjadi anak yang Saleh } \\
\text { dan Salehah serta berakhlakul karimah, karna bagi ante } \\
\text { jika anak sudah bisa menjadi anak yang Saleh maupun } \\
\text { Salehah akhlak pun bisa ikut menjadi baik, karna dilihat } \\
\text { pada saat sekarang ini banyak sekali para remaja yang } \\
\text { minim terhadap akhlaknya. }\end{array}$ \\
\hline
\end{tabular}

Berdasarkan hasil wawancara dan observasi dengan informan, hasil analisis secara nyata mendapati bahwa motivasi ekstrinsik orang tua dalam menyekolahkan anaknya di SD Islam Terpadu Albina sebagai berikut:

b. Motivasi ekstrinsik orang tua meyekolahkan anaknya di SD Islam Terpadu Albina Kecamatan Koto Baru Kabupaten Dharmasraya

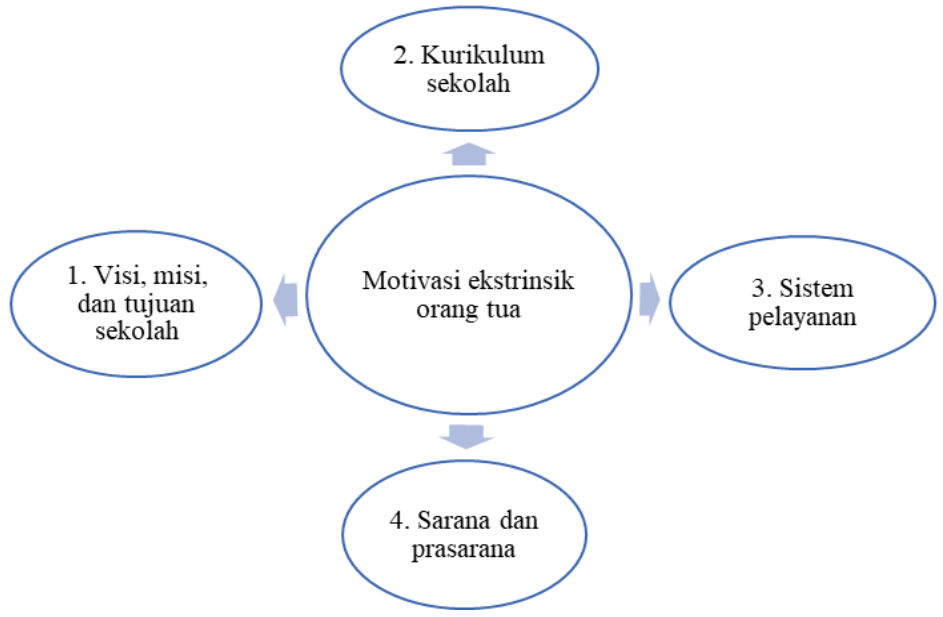


Gambar 2. Deskripsi Motivasi Ekstrinsik Orang Tua Meyekolahkan Anaknya di SD Islam Terpadu Albina Kecamatan Koto Baru Kabupaten Dharmasraya:

Tema 1: Visi, misi, dan tujuan sekolah. Penetapan tujuan pada umumnya didasarkan pada faktor-faktor kunci keberhasilan yang dilakukan setelah penetapan visi dan misi. Serta memenuhi harapan orang tua yang terbaik untuk anaknya kelak.

Tabel 2.1. Petikan Wawancara Tentang Visi, Misi dan Tujuan Sekolah

\begin{tabular}{l|c|l|}
\hline Tema & Informan & Petikan Wawancara \\
\hline Visi, misi, & 8 & $\begin{array}{l}\text { Dengan adanya visi sekolah yaitu: Terciptanya sekolah unggul } \\
\text { dang membentuk generasi intelektual dan Qur'ani, serta misi } \\
\text { sekolah salah satunya mewujudkan sekolah yang dikelola } \\
\text { tujuan } \\
\text { sekolah }\end{array}$ \\
$\begin{array}{l}\text { dengan nilai-nilai islami berdasarkan Al-qur'an dan As- } \\
\text { sunnah, membuat saya mempunyai harpan agar anak saya } \\
\text { menjadi berhasil kelak tentunya. }\end{array}$ \\
$\begin{array}{l}\text { Saya mengetahui adanya visi, misi dan tujuan SDIT Albina ini } \\
\text { dari brosur, maka dari itu saya tertarik untuk menyekolahkan } \\
\text { anak saya di SDIT Albina ini karena sangat sesuai dengan } \\
\text { harapan saya. }\end{array}$
\end{tabular}

Tema 2: Kurikulum sekolah. Dalam aplikasinya Sekolah Islam Terpadu menerapkan pendekatan penyelenggaraan dengan memadukan pendidikan umum dan pendidikan agama menjadi satu jalinan kurikulum. Dengan pendekatan ini semua mata pelajaran dan semua kegiatan sekolah tidak lepas dari bingkai ajaran nilai Islam. Dapat dilihat dari hasil wawancara dengan informan pada tabel sebagai berikut:

Tabel 2.2. Petikan Wawancara Tentang Kurikulum Sekolah

\begin{tabular}{l|c|l}
\hline Tema & Informan & Petikan Wawancara \\
Kurikulum & 1 & $\begin{array}{l}\text { Yang saya ketahui tentang SDIT Albina adalah sekolah Islam } \\
\text { sekolahg latar belakang ilmu agamanya lebih banyak di banding } \\
\text { sekolah lain. Kepercayaan kami 100\%. Karena kurikulum yang } \\
\text { dipakai pun juga sama dengan sekolah lain bedanya SDIT ini } \\
\text { memadukan pendidikan umum dan pendidikan agama } \\
\text { menjadi satu jalinan kurikulum }\end{array}$ \\
& 10 & $\begin{array}{l}\text { "...Saya menyekolahkan anak saya di SDIT Albina ini karena } \\
\text { kurikulumna mencakup, baik itu yang bersifat umum dan } \\
\text { berbasis agama serta tidak terlepas dariajaran Agama Islam. }\end{array}$ \\
&
\end{tabular}

Tema 3: Sistem pelayanan. Dengan adanya sistem pelayanan yang baik dari sekolah, sudah membuat orang tua merasa sangat di hargai dan di layani keinginannya. Sistem pelayanan yang ramah, sopan, membuat orang tua makin termotivasi menyekolahkan anak di SDIT Albina Kecamatan Koto Baru Kabupaten Dharmasraya.

Tabel 2.3. Petikan Wawancara Tentang Sistem Pelayanan

\begin{tabular}{|l|c|l|} 
Tema & Informan & Petikan Wawancara \\
\hline $\begin{array}{l}\text { Sistem } \\
\text { pelayanan }\end{array}$ & 2 & $\begin{array}{l}\text { Dilihat dari cara melayani saja sudah sangat senang hati } \\
\text { kami, apalagi sampai menyekolahkan anak di sekolah SDIT } \\
\text { Albina, berharap dengan adanya pelayanan yang baik maka }\end{array}$
\end{tabular}


Rasi Muliya dan Ahmad Rivauzi: Motivasi Orang Tua Memilih Sekolah Berbasis...

setiap persolan pun dapat di atasi dengan baik pula
Pelayanan dari ustad dan ustadzahnya ramah-ramah dan
sopan sehingga membuat saya merasa sangat dihargai dan
saya berharap keinginan saya terhadap anak itu juga
tercapai nantinya.

Tema 4: Sarana dan prasarana. Sarana dan prasarana adalah proses pengadaan dan pendayagunaan komponen-komponen yang secara langsung maupun tidak langsung jalannya proses pendidikan untuk mencapai tujuan pendidikan secara efektif dan efesien

Tabel 2.4. Petikan Wawancara Tentang Sarana dan Prasarana

\begin{tabular}{|c|c|c|}
\hline \multirow{3}{*}{$\begin{array}{l}\text { Tema } \\
\text { Sarana } \\
\text { dan } \\
\text { prasarana }\end{array}$} & Informan & Petikan Wawancara \\
\hline & 6 & $\begin{array}{l}\text { Kelebihan yang saya ketahui dari SDIT Albina ini adalah } \\
\text { sarana dan prasarana yang memadai, yang lengkap. Jadi, } \\
\text { dengan demikian dapat memudahkan proses jalannya } \\
\text { pendidikan bagi peserta didiknya }\end{array}$ \\
\hline & 5 & $\begin{array}{l}\text { Adanya sarana dan prasarana yang lengkap bisa } \\
\text { memudahkan siswanya untuk menyalurkan bakat serta } \\
\text { memudahkan semua kegiatan berkaitan dengan pendidikan }\end{array}$ \\
\hline
\end{tabular}

\section{Simpulan}

Motivasi instrinsik dan ekstrinsik orang tua dalam memilih sekolah untuk anaknya agar pemenuhan rasa aman terhadap anaknya sehingga dapat menjadikan anak yang mempunyai ketrampilan dan pengetahuan keagamaan (berprestasi), terwujudnya anak yang Saleh dan Salehah serta berakhlak mulia. Dan dengan adanya visi, misi dan tujuan sekolah, kurikulum sekolah, sistem pelayanan sekolah yang baik, serta adanya sarana dan prasarana yang memadai dapat mewujudkan tercapainya tujuan dari pendidikan serta terwujudnya harapan dari setiap orang tua yang memilih SDIT Albina untuk sekolah anaknya.

Salah satu hasil wawancara dengan orang tua yang menyekolahkan anaknya di SDIT Albina yaitu: "Saya sangat berharap pihak sekolah memberikan yang terbaik terhadap anak saya, mendidik serta mengayomi anak saya kepada hal-hal yang positif agar tercapainya pendidikan yang diinginkan" (Wawancara dengan Ibu Lusi, 07 April 2021).

Dari 236 jumlah orang tua yang menyekolahkan anaknya di SDIT Albina yang menjadi faktor instrinsik yang paling dominan orang tua dalam menyekolahkan anaknya ialah harapan terwujudnya anak yang Saleh dan Salehah serta berakhlak mulia. Sedangkan faktor ektrinsik yang paling dominan dari orang tua karna adanya visi, misi dan tujuan sekolah.

\section{Referensi}

Islamuddin, Idi. (2012). Psikologi Pendidikan. Yogyakarta: Pustaka Pelajar.

Kompri. (2015). Motivasi Pembelajaran Perspektif Guru dan Siswa. Bandung: PT Remaja Rosdakarya.

Lexy J. Moleong. (2017). Metodologi Penelitian Kualitatif. Bandung: PT Remaja Rosdakarya.

Sanjaya, Wina. (2013). Penelitian Pendidikan: Jenis, Metode dan Prosedur. Jakarta: Perdana

Media Grup.

Herminarto Sofyan \& Hamzah B. Uno. (2012). Teori Motivasi dan Penerapannya dalam

Penelitian. Yogyakarta: UNY Press.Emda, A. (2018). Kedudukan motivasi belajar siswa dalam pembelajaran Lantanida.Journal, 5(2), 172-182. 
http://103.107.187.25/index.php/lantanida/article/view/2838.

Mustofa, D. (2021) Motivasi Belajar Bahasa Arab Siswa MA AL Mubarok Uman Agung Bandar Mataram Lampung Tengah. DIMAR: Jurnal Pendidikan Islam, 2(2), 035-061.

http://ejournal.stit-almubarok.ac.id/index.php/DIMAR/article/view/47.

Nafisa, A. K. K, \& Savira, S. I. Hubungan Antara Religiusitas Terhadap Kenakalan Remaja.

https://ejournal.unesa.ac.id/index.php/character/article/view/41732.

Prihartanta, W. (2015). Teori-teori motivasi.Jurnal Adabiya, 1(83), 1-14. https://www.academia.edu/download/40847896/teori_motivasi.pdf.

Rijali, A. (2019). Analisis data kualitatif. Alhadharah: Jurnal Ilmu Dakwah, 17(33),81-95. http://jurnal.uinantasari.ac.id/index.php/alhadharah/article/view/2374.

Suprihatin, S. (2015). Upaya guru dalam meningkatkan motivasi belajar siswa. Jurnal $\begin{array}{lllll}\text { Pendidikan Ekonomi } & \text { Metro, 3(1), }\end{array}$ http://ojs.fkip.ummetro.ac.id/index.php/ekonomi/article/view/144 